Original Research Paper

\title{
Evaluation of Fibrous Diets for Finishing Pigs: Digestibility, Performance and Carcass Traits
}

\author{
${ }^{1}$ Bernardo Berenchtein, ${ }^{2}$ Adibe Luiz Abdalla, ${ }^{2}$ Patrícia Pimentel Santos Riguetto, \\ ${ }^{2}$ Adibe Luiz Abdalla Filho, ${ }^{2}$ Paulo de Mello Tavares Lima, ${ }^{1}$ Nerandi Luiz Camerini, \\ ${ }^{1}$ Hugo von Linsingen Piazzetta, ${ }^{3}$ Noédson Jesus Beltrão Machado and ${ }^{1}$ Alessandro Ulrich \\ ${ }^{1}$ Federal University of South Frontier, Erechim Campus, 99700-000, Erechim, RS, Brazil \\ ${ }^{2}$ Centre of Nuclear Energy on Agriculture, University of São Paulo, 13400-970, Piracicaba, SP, Brazil \\ ${ }^{3}$ Federal Rural University of Rio de Janeiro, 23890-000, Seropédica, RJ, Brazil
}

Article history

Received: 19-04-2018

Revised: 11-09-2018

Accepted: 09-02-2019

Corresponding Author: Bernardo Berenchtein

Federal University of South

Frontier, Erechim Campus, 99700-000, Erechim, RS, Brazil Tel. +55 5433217051

Email: bernardo.berenchtein@uffs.edu.br

\begin{abstract}
Two experiments were conducted to evaluate digestibility, performance and carcass traits of finishing pigs fed fibrous diets, such as, basal diet (Control treatment) and inclusion of Tifton-85 hay, Soybean hulls or Citrus pulp. Twenty crossbred castrated male pigs, with average body weight of $70.00 \pm 1.95 \mathrm{~kg}$, distributed in a randomized block design with four treatments and five repetitions (blocks) were used to evaluate apparent total tract digestibility of dietary nutrients. To evaluate animal performance and carcass traits, eighty commercial hybrids pigs with 120 days of age and average body weight of $73.00 \pm 3.3 \mathrm{~kg}$ were used. Pigs were distributed in 40 boxes according to gender and body weight, with one castrated male and one female pig per pen (experimental unit), in a randomized block design with 10 repetitions (blocks) per treatment were used. Regarding the digestibility assay, Tifton hay presented $2425 \mathrm{kcal}$ of digestible energy $/ \mathrm{kg}$, with low digestible protein content (3.36\%). Citrus pulp presented 2850 $\mathrm{kcal}$ of digestible energy/ $\mathrm{kg}$, also with low digestible protein content (1.47\%). Soybean hulls showed $2250 \mathrm{kcal}$ of digestible energy/kg, with relatively medium crude protein digestibility coefficient $(7.85 \%)$. Offering different fiber sources in the finishing phase for pigs promoted significant differences $(\mathrm{p}<0.05)$ in animal performance parameters (daily weight gain, daily feed intake and feed conversion) and no significant effect $(p>0.05)$ was observed for carcass parameters. Given the results obtained in this study, Soybean hull showed to be a promising ingredient to be used in diets of finishing pigs, leading to good results on animal performance and also contributing to the sustainability of pig production.
\end{abstract}

Keywords: Tifton Hay, Soybean Hulls, Citric Pulp

\section{Introduction}

World pig production, like other agribusiness, has grown significantly in recent years. Given this growth, an extremely important factor is the degree of nutritional competition that pigs present in relation to the human species. Approximately $75 \%$ of raw materials used directly in human nutrition are also designed for this species (Ludke, 2000). Based on that, it is clearly necessary to reformulate nutrition and feeding system for pigs. This can be done through studies to investigate the ability of these animals to use alternative sources of energy and/or protein, which are preferably not used in human diet and are generally available at a lower cost to the producers, which is the case of several fibrous feeds.
The possibility of using forages and grasses in pig nutrition has been theorized by Carroll (1936). However, studies on the potential of various fibrous sources on swine production regarding the identification, quantification and evaluation of interactions between the physiological and associative effects on digestibility and animal performance are needed, given the limited ability of the digestive tract of these animals to process this fibrous feedstuff.

The dietary fiber term is directly related to plant cell wall components i.e., structural carbohydrates such as cellulose, hemicellulose, pectin and lignin (Mertens, 1992), that are degraded into short chain fatty acids during the process of enteric fermentation in the large 
intestine (Gomes et al., 1994), accounting for 30\% of the energy requirements for animal maintenance (Kennelly et al., 1981; Rerat et al., 1987).

The purposes of this study are as follows: (1) To determine the nutrient apparent digestibility of different fibrous sources (Tifton-85 hay, Soybean hulls and Citrus pulp) for finishing pigs (Experiment 1); (2) to evaluate growth performance and carcass traits of finishing pigs fed with different fibrous sources (Experiment 2).

\section{Materials and Methods}

\section{Experiment 1 - Apparent Total Tract Digestibility (ATTD) Assay}

This study was conducted in the facilities of the Animal Nutrition Laboratory, of the Center for Nuclear Energy in Agriculture of the University of São Paulo, Piracicaba, São Paulo, Brazil (LANA-CENA/USP). In a 12 day experimental period (7 days of adaptation to diets and cages and 5 days of collection) 20 crossbred (Landrace $\times$ Large White $\times$ Pietrain) castrated male pigs, averaging $70.0 \pm 1.2 \mathrm{~kg}$ of Body Weight (BW) were used in an experiment to determine the Apparent Total Tract Digestibility (ATTD) of each fibrous source. Animals (experimental unit) were distributed in four treatments with five replications each in a completely randomized block design. They were individually allocated in metabolic cages, which allowed the separate collection of urine and feces, as described by Pekas (1968).

Pigs were fed a reference diet which was formulated according to Rostagno et al. (2011). Dry matter (DM), Crude Protein (CP) and Gross Energy (GE) analyses of diets were performed according to Silva and Queiroz (2002). Neutral Detergent Fiber (NDF) was determined according to Mertens (1992), Acid Detergent Fiber (ADF) and Lignin (LIG) were sequentially determined following the methodology proposed by Van Soest et al. (1991). By the difference between NDF, ADF and LIG, Hemicellulose (HEMI) and Cellulose (CEL) were calculated.

Treatments were formulated according to the fibrous ingredient employed as a $20 \%$ replacement of the reference diet (i.e., Citrus pulp, Soybean hulls or Tifton85 hay). Diets were offered twice a day (08:00 and $16: 00)$ according to metabolic Body Weight $\left(\mathrm{BW}^{0.75}\right)$ of animals and moistened in a 1:1 water and food ratio. Ferric oxide $\left(\mathrm{Fe}_{2} \mathrm{O}_{3}\right)$ was added to the diets as a marker to indicate the beginning and end of the fecal collection and determination of ATTD was performed using the total feces and urine method.

From the Average Feed Intake (AFI) observed in the adaptation period, the Amount of Restricted Feed (ARF) was established and employed in the days of excreta collection, according to the following calculations:
$\mathrm{ARF}=\mathrm{I} \times$ Metabolic Body Weight

where, $\mathrm{ARF}=$ amount restricted feed $(\mathrm{kg}) ; \mathrm{I}=$ Index $=$ AFI (kg)/Metabolic Body Weight; Metabolic Body Weight $(\mathrm{kg})=\mathrm{BW}^{0.75}$.

The index (I) was calculated for all animals, however, the lowest I value was adopted to calculate the ARF.

Despite I value standardization, ARF were individually calculated according to each animal weight.

Urine was daily collected in plastic buckets, filtered in cheesecloth then total volume was measured and a $20 \%$ sample was stored under refrigeration at $-20^{\circ} \mathrm{C}$. In each bucket used for urine collection, $20 \mathrm{~mL}$ of $1: 1$ solution of hydrochloric acid and distilled water was added to prevent microbial growth and nitrogen volatilization. The GE and nitrogen analyzes were performed on urine samples and nitrogen balance, metabolizable energy and energy metabolization coefficient were calculated according to the methodology proposed by Adeola (2001). Excreta samples from the rectum of the animals were collected twice daily and immediately placed in plastic bags, identified and frozen at $-20^{\circ} \mathrm{C}$. After, these samples were thawed under ambient conditions and homogenized into a single composite sample. Then samples were dried in forced air circulation ovens at $65^{\circ} \mathrm{C} 88$ for $72 \mathrm{~h}$ and ground in a Willey mill to pass through a $1 \mathrm{~mm}$ sieve followed by DM, GE, CP, NDF and ADF analysis (Silva and Queiroz, 2002). In addition, the apparent Digestibility Coefficients (DC) of DM, GE, CP, NDF and ADF and were calculated as well as the digestible nutrients of diets.

\section{Experiment 2 - Growth Performance and Carcass Traits}

\section{Animals and Housing}

The experiment was carried out on a commercial operation (St. Peter Pig Farm, Cordeirópolis, São Paulo, Brazil). The pigs were housed in $4 \mathrm{~m}^{2}$ pens with partially slatted concrete floor, single spaced semiautomatic feeder and a nipple drinker in a naturally ventilated building. Feed and water were provided ad libitum to pigs throughout the entire 30 days growth study. Before starting the experiment, all animals were transferred to the finishing phase facilities where they received a basal diet for 1 week. Eighty crossbred (Landrace $\times$ Large White $\times$ Pietrain) pigs, averaging $73.0 \pm 3.3 \mathrm{~kg} \mathrm{BW}$ and 120 days of age were distributed into 4 treatments with 6 replicate pens, with 1 castrated male and 1 female per pen in a completely randomized block design.

\section{Treatments}

The dietary treatments consisted of a corn-soybean meal basal diet (control treatment) and inclusion of fibrous sources (Tifton-85 hay, Soybean hulls, Citrus pulp; Table 2). The isoproteic and isoenergetic diets were formulated based on the nutrient requirements of finishing pigs (Rostagno et al., 2011). Diets were formulated with 
different fiber sources aiming an NDF content increase of $8 \%$, considered as optimal by Gomes (2006).

\section{Growth Performance and Carcass Traits Evaluation}

Individual pig BW and pen feed disappearance were recorded at $7 \mathrm{~d}$ intervals during the experimental period to determine Average Daily Gain (ADG), Average Daily Feed Intake (ADFI) and Feed Conversion Ratio (FCR). In the end of $30 \mathrm{~d}$ growth study, 1 pig per experimental unit ( 3 males and 3 females/treatment) were slaughtered, scalded, de-haired and eviscerated. Immediately after evisceration, carcasses were weighed to calculate Hot Carcass Yield (HCY) then split longitudinally for the measurements of Carcass Length (CL), Backfat Thickness118 (BT), Loin Eye Area (LEA) and Fat-toMeat ratio $(\mathrm{F} / \mathrm{M})$ according to the Brazilian Method for Carcass Evaluation (ABCS, 1973).

\section{Statistical Analysis}

The experimental design was a completely randomized block design with four treatments and ten repetitions per treatment. Statistical analysis of the data was performed using the $\mathrm{SAS} \AA \quad$ v.9.2 program (Statistical Analysis System Institute, Cary NC, USA). SAS LAB was used to verify the adequacy of the data to the linear model. Analysis of variance was performed using the GLM procedure and means were compared by Tukey test, adopting a 5\% significance level.

\section{Results}

The results of chemical composition, gross energy content, DC and DN of the different fibrous sources fed to finishing pigs are present in Table 1. Tifton hay presented $2425 \mathrm{kcal}$ of digestible energy $/ \mathrm{kg}$, with low digestible CP $(3.36 \%)$. It also showed 28.47 and $22.63 \%$ of digestible NDF and ADF, respectively. Citrus pulp presented 2850 $\mathrm{kcal}$ of digestible energy $/ \mathrm{kg}$, but low digestible CP $(1.47 \%)$. As for digestible NDF and ADF, values of 8.14 and $7.85 \%$ were observed, respectively. Soybean hulls introduced $2250 \mathrm{kcal}$ of digestible energy $/ \mathrm{kg}$, with high digestible protein with contents of $\mathrm{CP}(7.85 \%)$, due to the relatively high digestibility coefficient.

Table 1: Chemical composition, gross energy content, apparent digestibility coefficients (DC) and digestible nutrients (DN) of different fibrous sources fed to finishing pigs

\begin{tabular}{|c|c|c|c|c|c|c|c|c|c|}
\hline \multirow[b]{2}{*}{ Parameters } & \multicolumn{3}{|c|}{ Chemical composition } & \multicolumn{3}{|c|}{ Digestibility Coefficients } & \multicolumn{3}{|c|}{ Digestible Nutrients } \\
\hline & Tifton hay & Cytric pulp & Soybean hull & Tifton hay & Cytric pulp & Soybean hull & Tifton hay & Cytric pulp & Soybean hull \\
\hline $\mathrm{DM}(\%)$ & 93.90 & 90.19 & 91.32 & 65.00 & 89.10 & 55.63 & 61.06 & 80.35 & 50.80 \\
\hline GE (kcal/kg) & 3984.06 & 3650.00 & 3900.00 & 67.26 & 70.75 & 57.69 & 2425.78 & 2850.00 & 2250.00 \\
\hline $\mathrm{CP}(\%)$ & 5.21 & 10.48 & 10.72 & 64.55 & 14.00 & 73.20 & 3.36 & 1.47 & 7.85 \\
\hline NDF $(\%)$ & 74.67 & 20.86 & 68.09 & 38.00 & 39.00 & 31.87 & 28.47 & 8.14 & 21.70 \\
\hline $\operatorname{ADF}(\%)$ & 45.28 & 17.44 & 50.89 & 50.00 & 45.00 & 51.86 & 22.63 & 7.85 & 26.39 \\
\hline
\end{tabular}

DM - Dry Matter; GE - Gross Energy; CP - Crude Protein; NDF - Neutral Detergent Fiber; ADF - Acid Detergent Fiber

Table 2: Experimental diets ingredients composition and nutritional values

\begin{tabular}{lllll}
\hline Parameters & Control & Tifton hay & Cytric pulp & Soybean hull \\
\hline Ingredients composition (\%) & & & & 70.75 \\
Corn grain & 83.23 & 61.70 & 3.06 & - \\
Soybean oil & - & 7.61 & 16.72 & 12.98 \\
Soybean meal & 14.00 & 16.93 & 38.35 & 10.71 \\
8\% NDF source & - & 10.71 & 0.34 & 0.38 \\
Salt & 0.37 & 0.37 & 0.0013 & 0.61 \\
Limestone & 1.68 & 0.81 & 0.28 & 1.86 \\
Bicálcic Phosphate & 0.18 & 1.38 & - & 0.27 \\
DL- Metionine (99\%) & - & - & 0.30 & 0.40 \\
L-Lisine. HCl (78\%) & 0.33 & 0.29 & 0.10 & 0.10 \\
Vitamin supplement & 0.10 & 0.10 & 0.10 & 0.10 \\
Mineral supplement ${ }^{2}$ & 0.10 & 0.10 & 3233 & 3100 \\
Nutritional values & & & 13.83 & 13.83 \\
GE (Mcal/kg) & 3233 & 3230 & 17.00 & 17.41 \\
Crude protein (\%) & 13.83 & 13.83 & 0.86 & 0.86 \\
NDF (\%) & 11.47 & 17.43 & 0.76 & 0.76 \\
Total lysin (\%) & 0.86 & 0.86 & 0.35 & 0.31 \\
Calcium (\%) & 0.76 & 0.76 & 0.13 & 0.13 \\
Total phosphorus (\%) & 0.31 & 0.32 & 0.13 & \\
Available phosphorus (\%) & 0.13 & & & \\
\hline
\end{tabular}

${ }^{1}$ Quantities per kg: vit. A - 2520 UI; vit. D3 - 540 UI; vit. E - 9.9 UI; vit. K3 - 0.72 mg; tiamine - 404 mcg; riboflavine - 1.98 mg; piridoxine - $404 \mathrm{mcg}$; vit. B12 - $8.1 \mathrm{mcg}$; folic ácid - $225.2 \mathrm{mcg}$; pantotênic acid - $6.3 \mathrm{mg}$; niacine - $12.6 \mathrm{mg}$; Growth promoter - 10 mg; Se - 0.24 mg. ${ }^{2}$ Quantities per kg: Cu - 9 mg; Fe - 81 mg; I - 0.9 mg; Mn - 54 mg; Zn - 135 mg 
Table 3: Initial Body Weight (IBW), Final Body Weight (FBW), Average Daily Feed Intake (ADFI), Average Daily Gain (ADG), Feed Conversion Ratio (FCR), Hot Carcass Yield (HCY), Carcass Length (CL), Back fat Thickness (BT), Loin Eye Area (LEA) and Fat-to-Meat ration (F/M) of pigs fed control, Tifton hay, Cytric pulp and Soybean hull diets

\begin{tabular}{|c|c|c|c|c|c|}
\hline Parameters & Control & Tifton hay & Cytric pulp & Soybean hull & $\mathrm{SED}^{1}$ \\
\hline IBW (kg) & 70.52 & 71.12 & 70.27 & 72.13 & - \\
\hline FBW (kg) & $97.82^{b}$ & $97.52^{\mathrm{b}}$ & $81.53^{\mathrm{c}}$ & $108.73^{a}$ & 8.09 \\
\hline $\mathrm{ADG}(\mathrm{kg} / \mathrm{d})$ & $0.91^{\mathrm{b}}$ & $0.88^{\mathrm{b}}$ & $0.37^{\mathrm{c}}$ & $1.22^{\mathrm{a}}$ & 21.98 \\
\hline ADFI $(\mathrm{kg} / \mathrm{d})$ & $2.63^{\mathrm{b}}$ & $2.34^{\mathrm{c}}$ & $1.88^{\mathrm{d}}$ & $2.84^{\mathrm{a}}$ & 8.51 \\
\hline FCR & $2.89^{\mathrm{b}}$ & $2.65^{b}$ & $5.08^{\mathrm{c}}$ & $2.33^{\mathrm{a}}$ & 37.94 \\
\hline HCY (kg) & 81.72 & 80.54 & 80.30 & 80.24 & 3.70 \\
\hline CL (cm) & 90.65 & 90.04 & 88.80 & 87.78 & 3.23 \\
\hline BT (cm) & 2.13 & 2.30 & 2.39 & 2.42 & 14.92 \\
\hline $\operatorname{LEA}\left(\mathrm{cm}^{2}\right)$ & 35.25 & 35.13 & 34.11 & 34.12 & 9.44 \\
\hline $\mathrm{F} / \mathrm{M}$ & 0.38 & 0.39 & 0.39 & 0.41 & 15.31 \\
\hline
\end{tabular}

$\overline{\mathrm{abc}}$ - Means followed by different superscript letter differ significantly $(\mathrm{p}<0.05)$; SED - Standard Error Deviation

As for digestible NDF and ADF, Soybean hulls showed levels of 21.70 and $26.39 \%$, respectively. Table 3 presents the results of growth performance and carcass parameters of pigs fed the experimental diets. Offering different fiber sources for finishing pigs affected FBW, ADG, ADFI and FCR $(p<0.05)$. The highest FBW value was observed in pigs fed Soybean hull and the lowest ADG value was found for pigs fed Cytric pulp diet $(\mathrm{p}<0.05)$. Pigs fed Control and Tifton hay showed intermediate values for these parameters, without differing from each other $(\mathrm{p}>0.05)$. In addition, significant $(\mathrm{p}<0.05)$ values of ADFI were found for Soybean hull, Control, Tifton hay and Cytric pulp. Pigs fed Control and Tifton hay diets present similar ( $p>0.05)$ FCR values, being these higher than Soybean hull and lower than Cytric pupl diet $(\mathrm{p}<0.05)$. Significant effects were not observed ( $p>0.05$ ) for HCY, CL, BT, LEA and F/M parameters.

\section{Discussion}

Chemical analyses and feeding tests are the first items to determine feed nutritional potential. Animal species utilize feed nutrients differently and this variation may be quantified by determining their digestibility coefficients. Digestibility may be defined as the efficiency with which the animal digests and absorbs the nutrients and energy contained in a diet and digestibility determination of a specific ingredient is the first step when it comes to evaluating its potential for inclusion in animal diets (Pezzato et al., 2002).

The results of chemical composition, gross energy content, DC and DN of the different fibrous sources are in agreement with those presented in by the Brazilian requirements for poultry and swine tables (Rostagno et al., 2011) and also in accordance with the postulates of Gomes (2006) and Watanabe (2007), which evaluated the inclusion of "Coast Cross" hay and Citrus pulp in pig diets. Despite the fact that the digestibility of ingredients and not that of the diets was evaluated in the present study, for comparison purposes, Lun et al. (1988) found similar digestibility values for DM, CP, digestible energy and metabolizable energy in diets of growing pigs with $50 \%$ replacement of corn by triticale; however, increased dietary fiber resulted in a decrease in CP apparent digestibility, absorbed and fecal nitrogen, which likely was due to the higher microbial protein synthesis in the large intestine and hence, increased bacterial nitrogen excretion (Sauer et al., 1991), thus decreasing protein digestibility.

According to Gomes et al. (2007) the reduction of DM digestibility in diets containing increased NDF content may be attributed to the replacement of a highly digestible carbohydrate (corn starch) source by a less digestible one such as grass hay, rich in non-starch polysaccharides. These are widely known for its reduced degree of fermentability and they may also lead to faster passage rate of digesta through the gastrointestinal tract, which reduces their fermentation as well.

As observed in our study, Watanabe (2007) showed that Citrus pulp had high digestibility coefficient (72.60\%), possibly due to increased soluble crude fiber, subject to greater fermentation. These authors also stated that the effects of the inclusion of fiber sources on feed digestibility varies according to the solubility of their constituents. In view of the present results of this study, we can conclude that given the fact that pigs in the finishing phase already present complete development of the digestive system, they are capable of degrading the diverse fiber177 components, especially in the cecum, varying according to the NDF and ADF content of the evaluated ingredient.

Concerning growth performance and carcass traits evaluation, several studies were performed evaluating the inclusion of different levels of fibrous sources the diet, however, this study did not aim to evaluate the inclusion levels, but to determine which one of our fiber sources would generate more benefits by including them in the nutritional matrices of finishing pigs, representing an addition of $8 \%$ NDF, as theorized by Gomes (2006). 
The most promising results for FBW, ADG and FCR were observed in animals fed Soybean hulls. In the literature, there are very few studies with pigs fed on Soybean hulls, especially comparing to different fiber sources. And still, since it is a by-product of Soybean oil production, there is no such thing as a standardized production, making the comparison of different sources of Soybean hulls inadequate.

Shriver et al. (2003), included $10 \%$ of Soybean hulls in diets for growing and finishing pigs and found no effects on performance and carcass characteristics. Similarly, pigs in growing and finishing phase fed isoenergetic diets with inclusion of $0,4,8,12$ and $16 \%$ of Soybean hulls showed no differences in ADFI, ADG and FCR.

Evaluating different inclusion levels $(0,5,10$ and $15 \%)$ of Soybean hulls in diets for pigs, Wang et al. (2009) pointed out that this by-product does not affect animal performance corroborating the results reported by Kornegay (1981) and Van Oeckel et al. (1998). Nevertheless, DeCamp et al. (2001) concluded that 10\% inclusion of Soybean hulls in finishing swine diets increased ADFI and improved FCR of the animals since diets are supplemented with an energy source such as Soybean oil. Still, this fact differs from results obtained in the present study because even without an energy supplementation, the animals showed better results.

Although the Soybean hulls treatment have shown a slight reduction in $\mathrm{ME}$, the consumption of this ingredient may have been increased in order to balance the reduction of metabolizable energy caused by the addition of fiber sources in diet (Huo, 1993).

By analyzing the experimental diets, it can be seen that they were isonutritives, with minor differences. However, the short-chain fatty acids derived from the fiber fermentation in the large intestine, although not quantified in this study, are likely to have provide additional energy to the animals (Kass et al., 1980), at levels which depend on the age and category of animal. This factor, however, was not considered in the calculation of the experimental diets.

The most remarkable results in this study, obtained when using Soybean hulls, are probably due to shortchain fatty acids such as acetic, propionic and butyric acid, generated by microbial digestion in the cecum of the pigs, which are subsequently by blood stream and participate in the Krebs cycle generating Adenosine Triphosphate (ATP), contributing to the energy metabolism of animals. The metabolizable energy value calculated for Soybean hulls treatment was $3100 \mathrm{kcal} / \mathrm{kg}$, however, considering the facts described above, this value was probably underestimated.

To achieve the inclusion of $8 \%$ NDF in the diets, it was necessary to include about $11 \%$ of Tifton hay and soybean hulls, while $39 \%$ of Citrus Pulp was necessary. Naturally, the high inclusion of citrus pulp resulted in reduction of animal performance, due to the decreased feed intake which is attributed to the astringent flavor of this ingredient. On the other hand the studies of Watanabe (2007) have demonstrated that the Citrus pulp has a high DM coefficient digestibility $(72.6 \%)$, possibly due to its high soluble fiber content available for gut fermentation.

The decreased performance of animals fed Tifton hay and Citrus pulp may be due to changes in nutrient absorption rate, especially protein and amino acids (King and Taverner, 1975).

Concerning carcass parameters, no effects were observed in the present study, diverging from Pond (1989) which reported benefits when introducing fibrous sources in pig diet regarding carcass characteristics. However other authors like Hale and Utley (1985), evaluated the inclusion of $20 \%$ of soybean hulls in pig diet and similarly to the results obtained here, no effects were observed on carcass characteristics. Given the results obtained in this study, Soybean hull showed to be a promising ingredient to be used in diets of finishing pigs, leading to good results on animal performance and also contributing to the sustainability of pig production.

\section{Conclusion}

Given the results obtained in this study, it can be concluded that soybean hulls is an excellent ingredient to be used in finishing pig diets.

\section{Acknowledgement}

The authors would like to thank CNPQ for financial support.

\section{Statement of Animal Rights}

All procedures performed in involving animals were in accordance with the ethical standards of the institution at which the studies were conducted (Ethics Committee on Animal Use of the Escola Superior de Agricultura "Luiz de Queiroz" - CEUA-ESALQ/USP Procotol No. 0127.2014).

\section{Author's Contributions}

B. Berenchtein, A.L. Abdalla, P.P.S. Riguetto, A.L. Abdalla Filho, P.M.T. Lima, N.L. Camerini, H.V.L. Piazzetta, N.J.B. Machado and Alessandro Ulrich

\section{Ethics}

This article is original and contains unpublished material. The corresponding author confirms that all of the other authors have read and approved the manuscript and there are no ethical issues involved. 


\section{References}

Adeola, O., 2001. Digestion and Balance Techniques in Pigs. In: Swine Nutrition, Lewis, A.J. and L.L. Southern (Eds.), CRC Press, Boca Raton, pp: 903-916.

ABCS, 1973. Método brasileiro de avaliação de carcaças. Associação Brasileira De Criadores De Suínos, Estrela.

Carroll, W.E., 1936. Possibilities of increasing the use of forage and roughage in swine production. Proceedings of the American Society of Animal Production, (SAP' 36), pp: 26-29.

DeCamp, S.A., B.E. Hill, S.L. Hankins, D.C. Bundy and W.J. Powers, 2001. Effects of soybean hulls in commercial diet on pig performance, manure composition and selected air quality parameters in swine facilities. J. Anim. Sci., 79: 252-252.

Gomes, B.V., A.C. Queiroz and C.A.A. Fontes, 1994. Estudo das características físico-químicas de fenos de palhas. II. Efeito sobre a degradabilidade "in situ" da matéria seca, proteína bruta e fibra detergente neutron. Revista da Sociedade Brasileira de Zootecnia, 23: 292-304.

Gomes, J.D.F., 2006. Efeitos do incremento da fibra em detergente neutro na dieta de suínos sobre a morfologia dos órgãos digestivos e não digestivos. Brazilian J. Vet. Res. Anim. Sci., 43: 202-209. DOI: 10.11606/issn.1678-4456.bjvras.2006.26500

Gomes, J.D.F., S.M. Putrino, C. Grossklaus, C.E. Utiyama and L.L. Oetting et al., 2007. Effects of increasing dietary fiber on digestibility, performance and carcass characteristics: I. growing and finishing gilts. Semina: Ciências Agrárias, 28: 483-492. DOI: $10.5433 / 1679-0359.2007 \mathrm{v} 28 \mathrm{n} 3 \mathrm{p} 483$

Hale, O.M. and P.R. Utley, 1985. Value of beagle 82 triticale as a substitute for corn and soybean meal in the diet of pigs. J. Anim. Sci., 60: 1272-1279. DOI: $10.2527 /$ jas $1985.6051272 \mathrm{x}$

Huo, G.C., 1993. Utilization of fibrous materials by the indigenous breed of pigs (Northeast mini pig). 1. Effects of dietary fibre on performance and backfat thickness. Pig News and Information, London.

Kass, M.L., P.J. Van Soest, W.G. Pond, B. Lewis and R.E. McDowell, 1980. Utilization of dietary fiber from alfalfa by growing swine. I. Apparent digestibility of diet components in specific segments of the gastrointestinal tract. J. Anim. Sci., 50: 175-191. DOI: $10.2527 /$ jas $1980.501175 x$

Kennelly, J.J., F.X. Aherne and W.C. Sauer, 1981. Volatile fatty acid production in the hindgut of swine. Canadian J. Animal Sci., 61: 349-361. DOI: $10.4141 /$ cjas81-043

King, R.H. and M.R. Taverner, 1975. Prediction of the digestible energy in pig diets from analyses of fibre contents. Anim. Product., 21: 275-284.

DOI: $10.1017 / \mathrm{S} 0003356100030749$
Kornegay, E.T., 1981. Soybean hull digestibility by sows and feeding value for growing-finishing swine. J. Anim. Sci., 53: 138-145. DOI: $10.2527 /$ jas $1981.531138 x$

Ludke, J.V., 2000. A finalidade da nutrição animal. Suinocultura Industrial, Porto Feliz.

Lun, A.K., J.A.H.M. Smulders, O. Adeola and L.G. Young, 1988. Digestibility and acceptability of OACC wintry triticale by growing pigs. Canad. J. Anim. Sci., 68: 503-510. DOI: 10.4141/cjas88-056

Mertens, D.R., 1992. Análise da Fibra e Sua Utilização na Avaliação de Alimentos E formulação de Rações. In: Simpósio Internacional em Ruminantes, pp: 188-212.

Pekas, J.C., 1968. Versatile swine laboratory apparatus for physiologic and metabolic studies. J. Anim. Sci., 27: 1303-1309. DOI: $10.2527 /$ jas 1968.2751303x

Pezzato, L.E., E.C. Miranda and M.M. Barros, 2002. Digestibilidade aparente de ingredientes pela Tilápia do Nilo (Oreochromis niloticus). Revista Brasileira de Zootecnia, 31: 1595-1604.

DOI: $10.1590 / \mathrm{S} 1516-35982002000700001$

Pond, W.G., 1989. Plant fibre utilization by pigs. Pig News Inform., 10: 13-15.

Rerat, A., M. Fiszlewicz, A. Giusi and P. Vaugelade, 1987. Influence of meal frequency on post-prandial variations in the production and absorption of volatile fatty acids in the digestive tract of conscious pigs. J. Anim. Sci., 64: 448-456.

DOI: $10.2527 /$ jas $1987.642448 x$

Rostagno, H.S., L.F.T. Albino, J.L. Donzele, P.C. Gomes and R.F. Oliveira et al., 2011. Tabelas Brasileiras Para Aves e Suínos - Composição de Alimentos e Exigências Nutricionais. 3rd Edição, Imprensa Universitária, Viçosa.

Sauer, W.C., R. Mosenthin, F. Ahrens and L.A. den Hartog, 1991. The effect of source of fiber on ileal and fecal amino acid digestibility and bacterial nitrogen excretion in growing pigs. J. Anim. Sci., 69: 4070-4077. DOI: 10.2527/1991.69104070x

Silva, D.J. and A.C. Queiroz, 2002. Análise de Alimentos, Métodos Químicos e Biológicos. 3rd Edição, Editora UFV, Viçosa.

Shriver, J.A., S.D. Carter, A.L. Sutton, B.T. Richert and B.W. Senne et al., 2003. Effects of adding fiber sources to reduced-crude protein, amino acidsupplemented diets on nitrogen excretion, growth performance and carcass traits of finishing pigs. J. Anim. Sci., 81: 492-502.

DOI: $10.2527 / 2003.812492 x$

Wang, Y., Y.J. Chen, J.H. Cho, J.S. Yoo and Y. Huang et al., 2009. Effect of soybean hull supplementation to finishing pigs on the emission of noxious gases from slurry. Anim. Sci. J., 80: 316-321. DOI: $10.1111 / \mathrm{j} .1740-0929.2009 .00637 . \mathrm{x}$ 
Watanabe, P.H., 2007. Polpa cítrica na restrição alimentar qualitativa para suínos em terminação. Unpublished Masters Dissertation, Universidade Estadual Paulista.

Van Oeckel, M.J., N. Warnants, M. De Paepe, M. Casteels and V.B. Ch, 1998. Effect of fibre-rich diets on the backfat skatole content of entire male pigs. Livestock Product. Sci., 56: 173-180.

DOI: 10.1016/S0301-6226(98)00190-0
Van Soest, P.J., J.B. Robertson and B.A. Lewis, 1991. Methods for dietary fiber, neutral detergent fiber and nonstarch polysaccharides in relation to animal nutrition. J. Dairy Sci., 74: 3583-3597.

DOI: $10.3168 /$ jds.S0022-0302(91)78551-2 